\title{
The Regulation of HIV-1 mRNA Biogenesis
}

\author{
Massimo Caputi \\ Charles E. Schmidt College of Medicine, \\ Florida Atlantic University
}

USA

\section{Introduction}

The machinery regulating the transcription and processing of the human immunodeficiency virus type 1 (HIV-1) genome has been extensively studied for the past two decades, leading to the characterization of a complex set of interactions between viral and cellular factors. Our understanding of the basic molecular mechanisms regulating the expression of cellular genes has been greatly advanced by the lessons learned from this virus. Studies aimed at the understanding of transcription, capping, polyadenylation, splicing and export of the viral transcripts have helped in modeling the mechanisms regulating transcriptional and posttranscriptional events in the cell. Recent developments in the field have also shown that, similarly to cellular genes, transcription and processing of the viral mRNAs are functionally coupled and can potentially be regulated by small non-coding RNAs.

HIV replication is a complex multistep process whereby, following the recognition of specific receptors and co-receptors on the host cell membrane, the virus enters the cell where the viral RNA genome is reverse transcribed and integrated into the cellular DNA. The integrated proviral genome is than transcribed by the host transcription machinery into a 9.2 $\mathrm{kb}$ primary transcript, which is alternatively spliced in mRNAs coding for the 9 viral genes. Tat and rev gene products are shuttled into the nucleus to aid the transcription process, the former, and export of unspliced transcripts, the later. Unspliced transcripts are packaged as viral genome into the nascent virions. Gag and $e n v$ gene products code for the structural components of the new virions while the pol gene codes for key enzyme required for viral integration into the target host cell, which are than packaged within the virions. The products of the Vif, Vpr, Vpu and Nef genes are not essential for viral replication but are required for HIV pathogenesis and infectivity in-vivo.

HIV-1 has developed a number of strategies to regulate the transcription and processing of its primary transcript. Interactions between viral RNA sequences, the host cell and viral proteins are necessary to express the nine gene products required for its replication. Alteration of the delicate balance between spliced and unspliced RNAs, or disruption of the viral RNA export pathway, can dramatically affect HIV-1 infectivity and pathogenesis (Amendt, et al., 1994, Jablonski \& Caputi, 2009, Pollard \& Malim, 1998, Purcell \& Martin, 1993, Stoltzfus \& Madsen, 2006, Wentz, et al., 1997). A better understanding of the mechanisms regulating the transcription and processing of the viral RNA may provide us with novel therapeutic targets. 


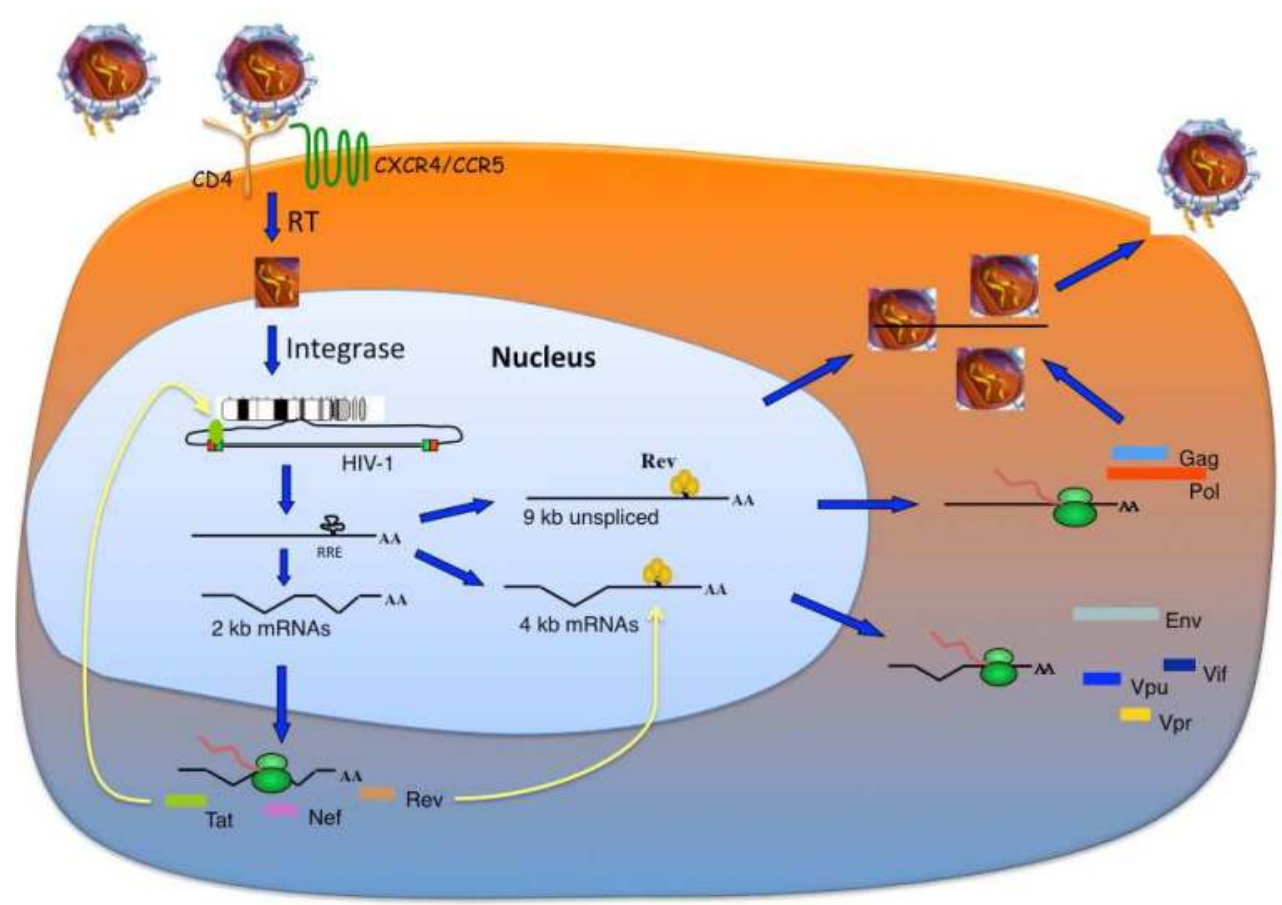

Fig. 1. The HIV-1 replication cycle. The key steps in the viral replication cycle: entry, integration, transcription, splicing export and assembly of the new virions are schematically shown together with the main viral gene products and their functions.

\section{HIV-1 transcription regulation}

Once the virus is integrated into the host cell chromosome the viral genome is transcribed into a single pre-mRNA from a complex promoter located within the $5^{\prime}$ long terminal repeat (LTR) of the viral genome. The HIV-1 LTR promoter contains two Sp1 binding motifs and two nuclear factor NF-kB binding sites which serves to regulate basal HIV-1 transcription (Pereira, et al., 2000). The LTR also contains binding elements for positive nuclear factor of activated T cells, AP-1, and negative, YY1 and LSF, transcriptional regulators. Tumor necrosis factor- $\alpha$ (TNF- $\alpha$ ) and other cytokines can induce NF-kb and activate HIV-1 transcription in infected cells (Van Lint, et al., 2004). Transcription regulation of the HIV-1 genome is mediated by RNA polymerase II (RNAP II) and a combination of basal and promoter specific factors (Fig. 2) (Brady \& Kashanchi, 2005, Pereira, et al., 2000).

Shortly after transcription begins RNAP II activity is paused. Before transcription is halted a short (nucleotides +1 to +82 ) stem loop sequence, the transactivation responsive (TAR) RNA, is synthesized. Binding of the 101 amino acid viral regulatory protein Tat to TAR stimulates transcription elongation and possibly initiation of the viral transcription complex (Fig. 2) (Berkhout, et al., 1989, Gaynor, 1995, Raha, et al., 2005). The Tat-TAR interaction promote the recruitment of the cyclin $\mathrm{T} 1$ (CycT1) component of the human positive 
transcription elongation factor b (P-TEFb) (Garber, et al., 1998, Wei, et al., 1998). CycT1 recruits Cdk9, the catalytic subunit of P-TEFb, which phosphorylates the C-terminal domain (CTD) of RNAP II to facilitate elongation of the viral transcript (Bres, et al., 2008, Peterlin \& Price, 2006). The mammalian RNAPII CTD is composed of 52 tandemly repeated heptads with a consensus, Tyr-1-Ser-2-Pro-3-Thr-4-Ser-5-Pro-6-Ser-7. Ser-2 and Ser-5 are targets of phosphorylation and dephosphorylation during transcription (Hirose \& Ohkuma, 2007). Phosphorylation of RNAPII CTD is essential for transcription. RNAPII CTD is phosphorylated at Ser-5 by TFIIH (CDK7) during transcription initiation through the promoter clearance stage (Hengartner, et al., 1998) and changes to Ser-2 phosphorylation during elongation when the polymerase is associated with the coding region (Komarnitsky, et al., 2000, Ni, et al., 2004). In addition to promoting Ser-2 phosphorylation, Tat modifies the activity of CDK9 to phosphorylate Ser-5 following release of TFIIH (Zhou, et al., 2000). Furthermore, P-TEFb targets cofactors such as the human homologoue of SPT5 (TAT-CT1), which together with SPT4 constitutes the 5,6-dichloro-1-ß-D-ribofuranosylbenzimidazole sensitivity-inducing factor (DSIF) and the negative elongation factor (NELF) Rd protein (Yamaguchi, et al., 1999). The cooperative interaction of DSIF and NELF induce polymerase pausing near promoter start sites (Wada, et al., 2000, Wada, et al., 1998b). This pausing event can be reversed by a CDK9dependent phosphorylation of SPT5 (Kim \& Sharp, 2001) and the RD protein, which causes a dissociation of NELF from the stem of TAR RNA (Fujinaga, et al., 2004).

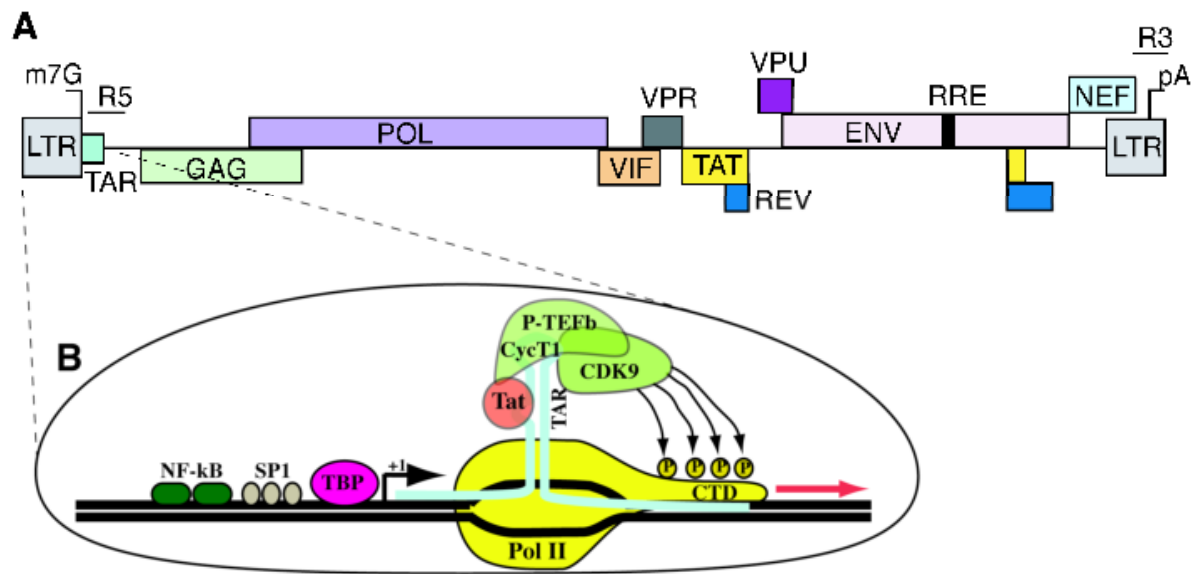

Fig. 2. A) The map shows the genomic organization of the HIV-1 provirus indicating the position of the various viral genes and key features of the viral genome. B) Schematic representation of viral transcription. A number of cellular transcription factors assemble onto the LTR promoter. Binding of Tat onto the TAR sequence promotes assembly of the components of P-TEFb (CycT1 and CDK9). The kinase activity of CDK9 phosphorylates the RNAPII CTD to facilitate elongation.

Tat role in viral transcription is not limited to the recruitment of RNAP II cofactors. Once integrated into the host cell genome, nucleosomes are deposited at specific positions within the viral promoter and exert a strong repression of transcriptional initiation. After Tat activates transcription, the chromatin associated with sequences immediately downstream of the transcription start site becomes accessible to nucleases (Verdin, et al., 1993). The 
chromatin remodeling induced by Tat is dependent on the recruitment of enzymes with histone acetyl transferase (HAT) activity, which modify chromatin conformation (Marcello, et al., 2001). These factors include the transcriptional co-activators p300 and the cAMPresponsive binding protein (CREB)-binding protein (CBP) (Marzio, et al., 1998), the p300/CBP-associated factor (P/CAF) (Benkirane, et al., 1998), the general control nonderepressible-5 (GCN5) factor (Col, et al., 2001), the transcription factor TAFII250 (Weissman, et al., 1998) and the TIP60 protein (Kamine, et al., 1996). HATs acetylate the Nterminal tails of histones to stimulate chromatin remodeling and modify specific lysines of transcription factors to modulate DNA-binding affinity (Li, et al., 2007, Yang \& Seto, 2008). In addition to histones, Tat itself is a substrate for acetylation by HATs. Lysines at positions 50 and 51 are major substrates for acetylation by p300 and hGCN5 (Col, et al., 2001, Deng, et al., 2001, Kiernan, et al., 1999). Acetylation of lysine 50 of Tat promotes the dissociation of Tat from TAR RNA during early transcription elongation and recruitment of the SWI/SNF chromatin-remodeling complex (Treand, et al., 2006), which synergize with p300 acetyltransferase and acetylated Tat to remodel the nucleosome at the HIV promoter in order to activate transcription (Mahmoudi, et al., 2006). Furthermore, acetylation of lysine 50 triggers the recruitment of P/CAF to the elongating RNA Pol II (Dorr, et al., 2002). P/CAF acetylates Tat on Lys28 (Kiernan, et al., 1999), which enhances the Tat-CycT1 interaction (Bres, et al., 2002). Besides acetylation other post-translational modifications appear to regulate Tat activity. Phosphorylation of Tat Ser16 and Ser46 by the cell cycle regulator Cdk2/cyclin E appears to be required for efficient HIV-1 transcription and replication (Ammosova, et al., 2006). Methylation of Tat on arginine residues by PRMT6 has been shown to inhibit transcriptional activity (Boulanger, et al., 2005), while non-proteolytic ubiquitination of Tat by Hdm2 appears to enhance viral transcription (Bres, et al., 2003).

In addition to its role in viral transactivation, Tat has also been shown to regulate the rate of transcription and expression of host cellular genes (Caldwell, et al., 2000, Gibellini, et al., 2002, Huang, et al., 1998, Ott, et al., 1998, Secchiero, et al., 1999). Furthermore, Tat function appears not to be restricted to infected cells, which actively secrete large amounts of Tat in the bloodstream (Ensoli, et al., 1990). Extracellular Tat can generate a wide array of cell responses ranging from $\mathrm{T}$-cell activation ( $\mathrm{Wu}$, et al., 2007) to stimulation of cytokine secretion, cell death in neurons and cell proliferation in endothelial and T-cells (Huigen, et al., 2004, King, et al., 2006, Rubartelli, et al., 1998). The mechanism by which Tat exerts these pleiotropic effects is still unclear.

\section{HIV-1 mRNA processing}

Before a gene transcript is ready to be transported out of the nucleus it has to be processed by acquiring a cap structure at the $5^{\prime}$ terminus, introns have to be spliced out and a $3^{\prime}$ end is generated by adding a poly(A) tail. Although these reactions are biochemically distinct processes, they are interlinked and influence one another's specificity and efficiency. Most mechanisms regulating the processing of viral transcripts are common to most cellular mRNAs, nevertheless some processes, such as the export of the unspliced and partially spliced mRNAs to the cytoplasm, are unique for the virus.

\subsection{Capping}

mRNA capping is carried out by a series of enzymatic reactions in which the $5^{\prime}$ triphosphate terminus of the pre-mRNA is cleaved to a diphosphate by a RNA triphosphatase (RTP), then 
capped with GMP by RNA guanylyltransferase (GT), and methylated by RNA (guanine-N7) methyltransferase (MT). Targeting of Cap formation to transcripts made by RNAP II is achieved through the interaction of the capping enzymes with the phosphorylated RNAPII CTD. The Cap structure is recognized by the Cap binding complex (CBC), which contains the proteins, CBP20 and CBP80 (Proudfoot, et al., 2002, Shatkin \& Manley, 2000). HIV-1 capping takes place during the transition from transcription initiation to elongation when the nascent pre-mRNA is only 20-40 nucleotides long. Tat promotes viral mRNA Cap formation by inducing TAR-dependent phosphorylation of RNAPII CTD (Chiu, et al., 2002, Zhou, et al., 2003) Phosphorylation of the CTD Ser-2 and Ser-5 residues has differential effects on recruitment and activation of capping enzymes (Bentley, 2002, Proudfoot, et al., 2002). Although Ser-2 phosphorylation of CTD heptads is sufficient for mammalian GT binding, its activation requires Ser-5 phosphorylated CTD (Ho \& Shuman, 1999).

\subsection{3' end formation}

In higher eukaryotes, with the exception of histone genes, all protein encoding mRNAs contain a uniform $3^{\prime}$ end consisting of 200-400 adenosine residues. The poly(A) tail regulates degradation of the mRNA and translation. The formation of the poly (A) tail is directed by sequences present on the pre-mRNA and the mammalian polyadenylation machinery. Prior to the addition of poly(A), the pre-mRNA must be cleaved. The site of cleavage, in most pre-mRNAs, lies between a highly conserved AAUAAA hexamer and a downstream sequence element (DSE), which is a U- or GU-rich motif. The cleavage/ poly(A) complex consists of cleavage factors (CPSF, CstF, CF) and the poly(A) polymerase (PAP). RNA is first cleaved $\sim 10$ to $30 \mathrm{nts} 3^{\prime}$ to AAUAAA, predominantly at a CA dinucleotide, than the PAP synthesizes a polyA tail using ATP as substrate (Proudfoot, et al., 2002, Shatkin \& Manley, 2000).

HIV-1 encodes the polyadenylation signal within the repeat $(\mathrm{R})$ region, which is present at the extreme $5^{\prime}$ and $3^{\prime}$ end of the viral transcript. Thus the $5^{\prime}$ polyadenylation signal needs to be repressed while usage of the $3^{\prime}$ one needs to be enhanced. Usage of the $3^{\prime}$ polyadenylation site is promoted by an upstream enhancer (USE) motif, which stabilizes binding of the cleavage polyadenylation specificity factor (CPSF) to the AAUAAA (Gilmartin, et al., 1995). The 5' HIV-1 polyadenylation site is repressed because it is positioned too close to the transcription initiation site and polyadenylation factors have not yet gained access to the nascent transcript through the RNAP II complex (Cherrington \& Ganem, 1992, Weichs an der Glon, et al., 1991). Moreover, binding of U1 snRNP to the major splice donor site, which is located downstream of $5^{\prime} \mathrm{R}$, represses polyadenylation at the $5^{\prime}$ polyadenylation signal (Ashe, et al., 1995, Ashe, et al., 1997). Cellular proteins can play a role in regulating cleavage and polyadenylation of HIV-1 RNA. hnRNP U has been shown to be involved in the post-transcriptional regulation of viral RNA via interactions with the 3' UTR (Valente \& Goff, 2006). The STAR (signal transduction and activation of RNA) protein family member Sam68 enhances HIV-1 gene expression and this effect may be due in part to Sam68's ability to stimulate cleavage of unspliced viral RNA (McLaren, et al., 2004, Reddy, et al., 1999). Experimental evidence also indicates a role for viral proteins in regulating the host polyadenylation machinery to render the cell more supportive of virus replication. The accessory protein $\mathrm{Vpr}$ induces polyA polymerase dephosphorylation and its subsequent activation (Mouland, et al., 2002), while Tat increases the expression of the cleavage and polyadenylation specificity factor (CPSF) (Calzado, et al., 2004). 


\section{3 mRNA Splicing}

The removal of intronic sequences in the nascent transcript is carried out by large multicomponent ribonucleoprotein complex, the spliceosome, constituted by five small nuclear ribonucleoprotein complexes (snRNPs, U1, U2, U4, U5, U6), which assembly onto the pre-mRNA requires auxiliary proteins called splicing factors (Moore, et al., 1993). The process of splicing involves recognition of short loosely conserved sequences flanking the introns. The U1 snRNP recognizes the $5^{\prime}$ splice site (5'ss) while the U2 snRNP in combination with the splicing factor U2AF65/35 recognizes sequences at the $3^{\prime}$ splice site ( $\left.3^{\prime} \mathrm{ss}\right) .5^{\prime}$ and $3^{\prime}$ splice sites are required for splicing but alone are not sufficient for the proper recognition of exonic and intronic sequences.

A

A
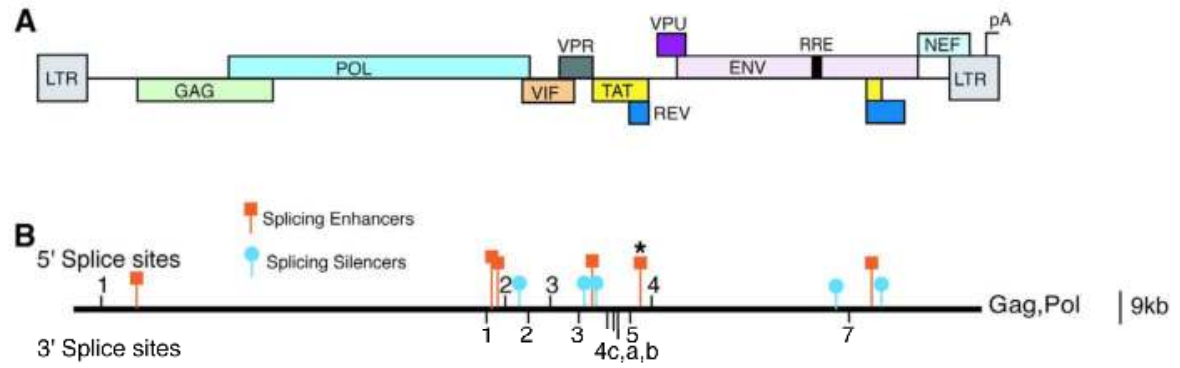

C

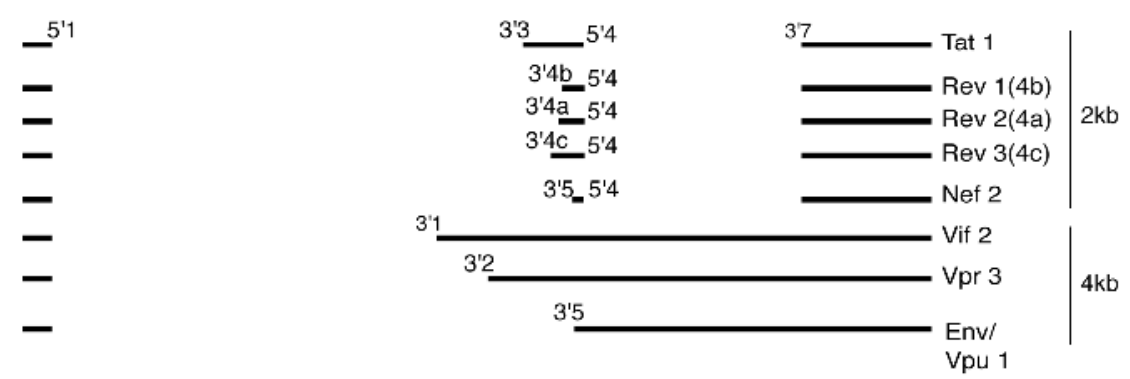

Fig. 3. A) The map shows the HIV-1 open reading frames. B) A single pre-mRNA of $9.2 \mathrm{~kb}$ is transcribed by the virus. $5^{\prime}$ and $3^{\prime}$ splice sites are indicated The unspliced viral mRNA codes for the Gag/Pol gene products. 5' and 3' splice sites are indicated. Splicing silencers (intronic and exonic) and splicing enhancers (intronic and exonic) are indicated. $\left({ }^{*}\right)$ marks the location of the GAR splicing enhancer (see Fig 5). C) Prevalent spliced viral mRNas. Over 40 alternatively spliced $\mathrm{mRNAs}$ are originated by the alternative usage of the multiple $5^{\prime}$ and $3^{\prime}$ splice sites, the most abundant mRNA isoforms are indicated with their approximate size and the splice site utilized to generate them.

Additional regulatory elements are classified as either exonic and intronic splicing enhancers (ESE and ISE) or exonic and intronic splicing silencers (ISS and ESS). These sequences can interact with factors that promote proper recognition of the splice sites and regulate splicing in response to physiological stimuli. Among the best-characterized ESEs are purine-rich sequences that recruit members of the serine/arginine-rich (SR) family of 
splicing activators (Blencowe, 2000). SR proteins regulate splicing by binding enhancer elements and recruiting and stabilizing components of the core splicing machinery to nearby splice sites (Graveley, 2000). Recent work implicates SR proteins in additional steps of gene expression, including mRNA export, stability, quality control and translation (Huang \& Steitz, 2005). The best-known ESSs are dependent on interactions with members of the heterogenous ribonucleoprotein A/B family (hnRNPs A/B) (Krecic \& Swanson, 1999). Positive and negative cis-acting sequences are often organized in multipartite control elements where SR proteins and hnRNPs often play counteracting roles (Caceres, et al., 1994, Han, et al., 2005, Zahler, et al., 2004).

Alternative splicing is a process common to most cellular mRNAs by which exons from a primary transcript (pre-mRNA) can be spliced in different arrangements to yield mRNAs that will produce functionally different protein variants (Black, 2003). The primary viral transcript undergoes a complex series of splicing events to generate over $40 \mathrm{mRNA}$ isoforms, thus, the same viral protein is encoded by multiple mRNAs that vary for their $5^{\prime}$ and 3' untranslated regions. Spliced viral mRNAs can be classified in a group of approximately $4 \mathrm{~kb}$ in length, coding for the Env, $\mathrm{Vpu}, \mathrm{Vpr}$ and Vif proteins, and a group of approximately $2 \mathrm{~kb}$ in length, coding for the Tat, Rev, Vpr and Nef proteins (Fig. 3C) (Purcell \& Martin, 1993). Furthermore, approximately 50\% of the viral pre-mRNAs leave the nucleus without being spliced. The unspliced $9 \mathrm{~kb}$ mRNA codes for the Gag and Gag-Pol polyprotein and is packaged within the nascent virions as viral genome. Alteration of this complex splicing pattern can have profound effects on viral replication and infectivity (Amendt, et al., 1994, Jablonski, et al., 2008, Jacquenet, et al., 2005, Purcell \& Martin, 1993). HIV-1 splicing regulation relies on the presence of multiple viral regulatory sequences as well as cellular splicing factors that interact with these elements. To date, 4 exonic splicing silencers (ESS), 1 intronic splicing silencer (ISS), 1 intronic splicing enhancer (ISE) and 6 splicing exonic enhancers (ESE) have been identified (Fig. 3B) (Exline, et al., 2008, McLaren, et al., 2008, Schaub, et al., 2007). Several SR proteins (SC35, SF2, SRp40, 9G8) have been shown to bind the viral splicing enhancers and regulate splicing, while members of the hnRNP A/B (A1, A2 and A3) family have been shown to inhibit the usage of viral splice sites by binding viral spicing silencer elements and counteracting the activity of SR proteins (McLaren, et al., 2008). A third group of proteins interacts with both, enhancer and silencer sequences, is the hnRNP $\mathrm{H}$ family ( $\mathrm{H}^{\prime}, \mathrm{F}, 2 \mathrm{H} 9$ and GRSF1). These are highly homologous and ubiquitously expressed factors, which regulate splicing, polyadenylation, capping, export and translation of cellular and viral mRNAs (Fogel \& McNally, 2000, Han, et al., 2005, Jablonski \& Caputi, 2009, Min, et al., 1995, Schaub, et al., 2007).

Cis-acting splicing regulatory elements within the HIV genome are highly heterogenous, redundant and provide for ample regulation of viral genome expression. In addition, the virus appears to directly regulate the relative amount and activity of cellular splicing factors in infected cells. HIV-1 infection has been shown to induce alteration in SR protein subcellular distribution, and activity via modificaton of their phosphorylation state by SRspecific kinases (Fukuhara, et al., 2006). Furthermore, data obtained from infected monocyte-derived macrophages demonstrate that a peak in viral production results in down-regulation of members of the hnRNP A/B, H and SR family, thus confirming the critical role that these proteins may play in viral replication. (Dowling, et al., 2008).

\section{4 mRNA export and stability}

In the early phase of viral infection the $2 \mathrm{~kb}$ class of viral RNAs (translated into Tat, Rev and $\mathrm{Nef}$ ) is exported to the cytoplasm while 9 and $4 \mathrm{~kb}$ viral RNAs are retained in the nucleus. 
Nuclear retention of 9 and $4 \mathrm{~kb}$ HIV-1 RNAs has been attributed to either partial spliceosome assembly (Chang \& Sharp, 1989) or to a series of of poorly characterized sequences called the instability (INS) or cis-acting repressor (CRS) sequences (Maldarelli, et al., 1991, Mikaelian, et al., 1996, Nasioulas, et al., 1994, Olsen, et al., 1992) present within the viral mRNA. These sequences restrict the expression of the $9 \mathrm{~kb}$ and $4 \mathrm{~kb}$ mRNA species. The mechanistic details of inhibition of gene expression by INS/CRS remains obscure, it has been proposed to involve increased splicing efficiency, prevention of nuclear export and degradation of INS/CRS containing RNAs or a combination thereof (Boris-Lawrie, et al., 2001, Reddy, et al., 2000, Wodrich \& Krausslich, 2001). The fully spliced $2 \mathrm{~kb}$ mRNAs are exported from the nucleus to the cytoplasm with a mechanism similar to the one utilized by the assembly of a protein complex at the junctions between exons (exon junction complex, EJC) during splicing (Rodriguez, et al., 2004). Additionally, factors directly binding to sequences within the RNA may contribute to efficient export (Huang \& Steitz, 2005).

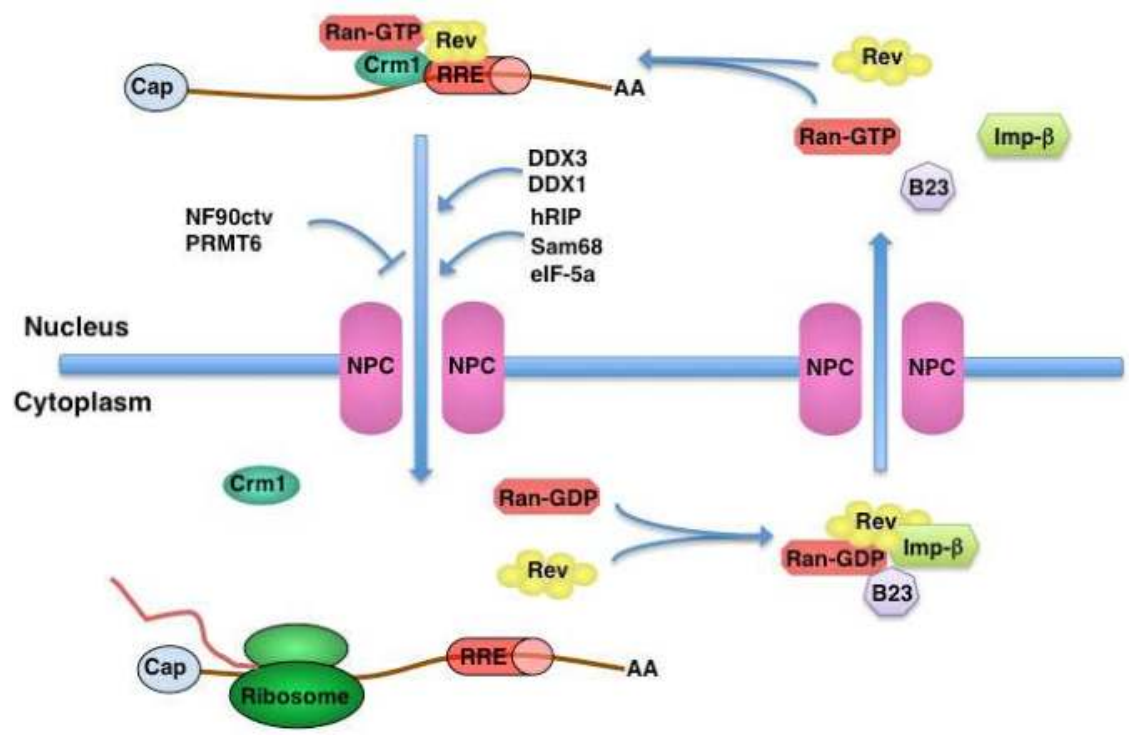

Fig. 4. HIV-1 RNA export to the cytoplasm. 9 and $4 \mathrm{~kb}$ viral RNAs are exported to the cytoplasm upon interaction of the Rev/Crm1/RanGTP complex with the RRE sequence within the RNA. The DDX1 and DDX3 helicases facilitate translocation of the Rev-RNA complex to the cytoplasm through the nuclear pore complex (NPC). Other host cell factors have positive (hRIP, SAM68, eIF-5a) or negative (NF90ctv, PRMT6) effects on the Revdependent export of the viral RNA but their role is less understood. Importin- $b$, RanGDP and B24 are required for import of Rev into the nucleus.

Nuclear retention of the unspliced and partially spliced viral mRNAs (9 and $4 \mathrm{~kb}$ ) is overcome by the viral protein Rev, which is imported into the nucleus and binds to an RNA element within the env gene, called the Rev Responsive Element (RRE), and mediates nuclear export and efficient expression of its target RNAs (Fig. 4) (Cullen, 2000, Cullen, 2003). All the $4 \mathrm{~kb}$ and $9 \mathrm{~kb}$ viral mRNA species contain the RRE element and in the absence of Rev are poorly expressed in the cytoplasm. Rev import from the cytoplasm into the 
nucleus is aided by importin- $\beta$ and the nuclear phosphoprotein B23. Following Rev binding to the RRE, the nuclear export factors CRM1 and Ran-GTP are recruited to the complex to promote export of the viral RNA into the cytoplasm. The Rev-RRE-CRM1-RanGTP RNA complex is finally dissociated in the cytoplasm upon conversion of RanGTP to RanGDP (Suhasini \& Reddy, 2009).

Little is known of cellular co-factors required by Rev-RRE other than the general nuclear export factors exportin CRM1 and RAN-GTP. RNA helicases DDX1 and DDX3 are known to associate with the Rev-CRM1-RRE complex and are postulated to aid the egress of the viral RNA through the nuclear pore by remodeling its structure (Fang, et al., 2004, Yedavalli, et al., 2004). Other factors such as the eukaryotic initiation factor eIF-5A (Bevec, et al., 1996, Ruhl, et al., 1993), the human Rev interacting protein (hRIP) (Bogerd, et al., 1995, Fritz, et al., 1995) and Sam68 (Reddy, et al., 1999) have also been shown to enhance Rev activity although their mechanism is still unclear. Cellular factors may also play an inhibitory role in Rev-dependent RNA export. The C-terminal variant of nuclear factor 90 (NF90ctv) has been shown to reduce Rev function by binding and partially relocalizing Rev to the cytoplasm (Urcuqui-Inchima, et al., 2006), while Rev methylation by the arginine methylase PRMT6 reduces Rev binding to the RRE and blocks viral RNA export (Invernizzi, et al., 2006).

\section{Transcription and mRNA processing coupling}

In recent years our view of gene expression has changed significantly. While a growing number of genetic studies have revealed functional links between the factors that carry out the different steps in the gene expression pathway, conventional biochemical approaches and large-scale mapping of protein-protein interaction networks have uncovered physical interactions between the various machineries (Orphanides \& Reinberg, 2002, Proudfoot, et al., 2002). The transcriptional apparatus plays an active role in recruiting the machinery that processes the nascent RNA transcript (Bentley, 2002, Bentley, 2005). The RNAPII CTD operates as a binding platform for components of the RNA processing machineries and its phosphorylation regulates the activity of the capping enzymes, assembly of the spliceosome and the binding of the cleavage/polyadenylation complex (Buratowski, 2003, Fong \& Bentley, 2001, Hirose \& Ohkuma, 2007, Komarnitsky, et al., 2000, Proudfoot, et al., 2002).

The mechanism coupling 5' RNA capping with transcription has been well studied. Binding of the DSIF factor (Wada, et al., 1998a, Wada, et al., 1998b) to RNAPII shortly after initiation recruits NELF (Yamaguchi, et al., 1999), which arrests transcription. The cdk7 subunit of the initiation factor TFIIH phosphorylates the RNAPII CTD Ser-5 between initiation and arrest (Woychik \& Hampsey, 2002). The paused RNAP II is then joined by the capping enzymes through interactions with the Ser-5 phosphorylated CTD and DSIF (Wada, et al., 1998b, Wen \& Shatkin, 1999). Following the addition of the Cap, the kinase activity of P-TEFb phosphorylates DSIF (Ivanov, et al., 2000, Kim \& Sharp, 2001), this neutralizes the repressive action of NELF and allows the polymerase to resume elongation. Similary $3^{\prime}$ End formation is also linked to transcription. The cleavage/polyadenylation factors CPSF and CstF are transferred by the RNAP II CTD to their specific pre-mRNA-binding sites to produce the mRNA $3^{\prime}$ end (Buratowski, 2005). Splicing and $3^{\prime}$ end formation machineries are also connected since repression of the polyadenylation signal within the R5 region is dependent on proximity to the promoter and recognition of the major $5^{\prime}$ splice site by the U1 snRNP (Ashe, et al., 1995, Ashe, et al., 1997). 
Several studies have also shown that transcription and splicing are closely connected processes. The rate of elongation, the promoter type, transcriptional activators and the chromatin remodeling factors nearby can all affect splicing of a pre-mRNA (Batsche, et al., 2006, de la Mata, et al., 2003, Kornblihtt, 2005, Kornblihtt, 2007). Again, the RNAPII CTD assumes a central role in the regulation of RNA splicing. Phosphorylation at Ser-2 position of the RNAPII CTD stimulates pre-mRNA splicing (Hirose, et al., 1999, Misteli \& Spector, 1999). Studies have identified several splicing factors that interact either directly or indirectly with the transcription machinery (Kameoka, et al., 2004, Kwek, et al., 2002). Many of the works published indicate processes that link the transcription machinery to premRNA splicing. However, a "reverse coupling" mechanism, whereby pre-mRNA splicing exerts an influence on transcription has also been described. Indeed, the SR protein SC 35 has been shown to affect transcription elongation (Lin, et al., 2008) and promoter-proximal 5' splice sites increase transcription initiation via recruitment of the transcription preinitiation complex (PIC) (Damgaard, et al., 2008).

Studies on the association between the viral transcription and splicing machinery are still in their infancy. Research indicates that the cellular factor Tat-SF1, which is required for efficient transcriptional transactivation of the viral genome (Parada \& Roeder, 1999, Zhou \& Sharp, 1996), is also interacting with spliceosomal components (Fong \& Zhou, 2001). The association with both elongation and splicing factors has led to the suggestion that Tat-SF1 can couple these two processes. Tat-SF1 also binds to another transcription-splicing coupling factor, CA150 (TCERG1) (Smith, et al., 2004). Over-expression of CA150 has been shown to reduce the ability of Tat to mediate viral transcription (Sune \& Garcia-Blanco, 1999). This function is dependent on the association of CA150 with pre-mRNA splicing factors and RNAPII CTD (Carty, et al., 2000, Goldstrohm, et al., 2001) and may bridge splicing complexes to actively transcribing RNAPII (Sanchez-Alvarez, et al., 2006). The cellular protein c-Ski-interacting protein, SKIP, has been shown to regulate Tat-dependent viral transcription and interact with the splicing associated U5 snRNP and the tri-snRNP 110K protein (Bres, et al., 2005). Studies also indicate the presence of a reverse coupling mechanism in HIV-1. U1 snRNA binding to a specific $5^{\prime}$ splice site within the viral genome appears to overcome a checkpoint for elongation present in the env gene intron (Alexander, et al. 2010).

The viral transactivator Tat has also been shown to regulate viral splicing through the ASF/SF2 inhibitor p32 (Berro, et al., 2006). p32 is recruited to the HIV-1 promoter by the acetylated form of Tat, suggesting a mechanism by which acetylation of Tat promotes binding of p32 and thereby inhibits HIV-1 splicing, thus increasing the amounts of unspliced transcripts available for being translated into gag/pol gene products and packaging into the nascent virions as viral genome. More recently we have shown that Tat is also a selective mediator of HIV-1 splicing (Jablonski, et al., 2010) via the recruitment of the cellular co-transcriptional splicing activators Tat-SF1 and CA150 (Fig. 5). The Tattranscription-splicing complex activates a distal splicing enhancer (GAR), which is required for env mRNA expression. In the context of the full-length viral genome, this mechanism promotes an autoregulatory feedback that decreases expression of Tat-coding mRNAs and favors expression of Env-specific mRNAs. Tat-mediated splicing does not appear to be dependent on its transcriptional activity. Substitution of the LTR promoter for the heterologous $\beta$-globin, promoter or down-regulation of Tat transcription co-factors SKIP and Tat-CT1 blocks Tat-mediated transactivation but not splicing. Tat appears to modulate splicing independent of its ability to functionally engage the transcription machinery and alter phosphorylation of the RNAP II CTD, defining a novel mechanism that couples 
transcription and RNA processing via the direct recruitment of splicing factors through transcription activators. We have also shown that, like Tat, mammalian transcriptional coactivators of the Torc family can also activate splicing of endogenous genes and that this activity is independent from their role in transcription (Amelio, et al., 2009). These observations provide support for a general mechanism whereby transcriptional activators, viral or cellular, can selectively regulate splicing processes.

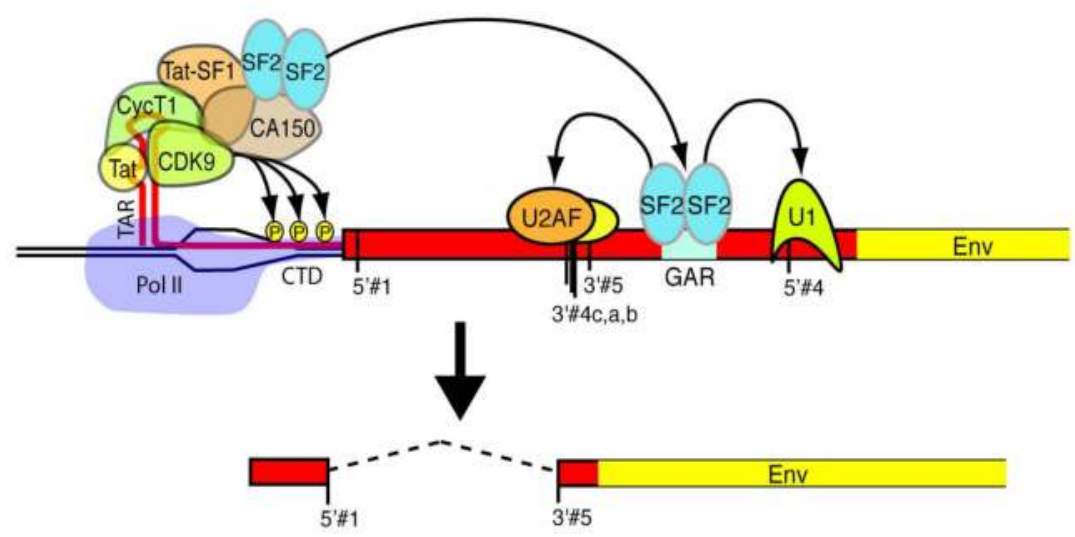

Fig. 5. Model for Tat-mediated splicing. Tat binding to TAR helps the recruitment of Tat-SF1 and CA150, which stimulates the assembly of the splicing factor SF2 onto the GAR enhancer (see Fig. 2). SF2 interaction with GAR promotes the upstream 3'ss and recruitment of U1 snRNP to the downstream 5'ss, which promotes expression of the env specific mRNA.

\section{HIV-1 derived microRNAs}

MicroRNAs (miRNAs) are short non-coding RNA molecules encoded by most eukaryotic life forms ranging from plants to higher order mammals. miRNAs have multiple pre- and post-transcriptional roles in the regulation of gene expression. The first step in the biogenesis of miRNA is the nuclear processing of primary RNA transcripts (pri-miRNAs) approximately 80 nucleotide long into shorter ( 60nt) pre-miRNAs, which are exported to the cytoplasm where pre-miRNA are further processed into mature miRNAs and assembled into a ribonucleoprotein complex named RISC (RNA-induced silencing complex) (Chua, et al., 2009, Perron \& Provost, 2008, Winter, et al., 2009). The RISC complex and the associated miRNA often contain sequences complementary to the 3' UTR region of the target mRNAs. Perfect complementarity between the target sequence and the miRNA triggers degradation of the target RNA. However, when miRNA and target mRNA sequences are only partially complementary the mRNA is translationaly repressed. Furthermore, miRNA can also operate at chromatine level. miRNAs have been shown to associate with the RNA-induced initiation of transcriptional silencing (RITS) complex and be recruited to complementary sequences in the chromosomal DNA. This promotes the activity of histone modifying enzymes, which alter the chromatin structure and induce transcriptional silencing (Buhler \& Moazed, 2007, Verdel, et al., 2004).

Several HIV-1 encoded non-coding RNAs have been identified. In particular, the stem-loop TAR sequence is structurally similar to a pre-miRNA and it has been shown to be processed 
into two functional miRNAs, the $5^{\prime}$ stem (miR-TAR-5p) and the $3^{\prime}$ stem (miR-TAR-3p) (Klase, et al., 2007, Klase, et al., 2009, Ouellet, et al., 2008). miR-TAR-3p acts as an inhibitor of cellular gene expression targeting genes regulating stress induced cell death (Klase, et al., 2009). The downregulation of the host machinery by viral miRNAs is part of the viral strategies to prolong the life span of an infected cell and allows for efficient viral replication and the emergence of latently infected cells. Additionally, it has been shown that the TARderived miRNA can downregulate gene expression by recruiting chromatin remodeling components, thus inducing transcriptional silencing via the RITS mechanism (Purzycka \& Adamiak, 2008).

A second miRNA is coded within the viral gene nef. Nef is a viral protein required for productive viral infection. It has been shown that miRNAs derived from nef transcripts are present in HIV-1 infected cells (Yamamoto, et al., 2002). Nef derived miRNAs appear to down regulate expression of the nef gene and they appear to be present in higher amounts in HIV-1 patients that are long time non-progressors and display low viremia.

A third miRNA generated by HIV-1, named miR-H1, is an 81 nucleotide stem loop structure present downstream of the two NF-kB sites in the LTR (Bennasser, et al., 2004). MiR-H1 has been shown to degrade the apoptosis antagonizing transcription factor (AATF) (Kaul, et al., 2009), which leads to lowered cell viability, thus counteracting the anti-apoptotic effect of the TAR-derived miRNAs. Furthermore, miR-H1 down regulates expression of the cellular miRNA miR149, which targets the Vpr gene encoded by HIV-1 (Kaul, et al., 2009). Studies on HIV-1 miRNA variability in different viral isolates have also shown that there is a strong correlation between specific miR-H1 sequences and the development of HIV-1-associated dementia and AIDS related lymphoma (Lamers, et al., 2009).

In addition to generating several viral miRNAs, HIV also regulates the cellular machinery that process small non-coding RNAs. The viral protein Tat appears to act as a generic suppressor of the activity of Dicer (Bennasser, et al., 2005), a key enzyme required for the maturation of small non-coding RNAs. Furthermore, the viral proteins Vpr and Nef have been shown to suppress the cellular miRNA machinery by suppressing production of Dicer (Coley, et al., 2011). Vertebrates have developed RNAi-based antiviral mechanisms. Given the presence in the HIV-1 genome of multiple regions that produce interfering RNAs, the anti-RNA silencing function of several viral proteins appears to be required to sustain viral replication in infected cells.

\section{Future prospective}

Different aspects of viral replication have been the targets of therapeutics; nevertheless, few efforts have been aimed at the disruption of the mechanism regulating viral RNA biogenesis. Formation of the HIV-1 transcript provides an important model for human RNA processing pathways and can be crucial in the isolation of novel therapeutic targets to block viral replication. Cellular factors regulating HIV RNA are expressed in most cell types and regulate a multitude of cellular splicing events theoretically making them less ideal therapeutic target candidates. Nevertheless, several drugs inhibiting different aspects of Tat transactivation are currently being tested. Different classes of compounds have been shown to specifically inhibit viral transcription by: (i) binding the TAR sequence, (ii) binding Tat, (iii) inhibiting PTEF-b components and (iv) generally inhibiting transactivation by mechanisms not yet well defined (Giacca, 2004). Small molecules that inhibit the splicing activity of SR proteins have also been shown to efficiently repress viral replication in 
peripheral blood mononuclear cells (PBMC) with little cell toxicity (Bakkour, et al., 2007). Furthermore, the possibility of utilizing delivery systems that specifically target cells infected by the virus (Neff, et al., 2011, Peretti, et al., 2006) suggest that cellular factors regulating the making of the viral RNA can be efficiently targeted to inhibit viral replication.

\section{Acknowledgement}

I thank Edwin Meagher for advice on the manuscript and Michelle Caputi for help in preparing it. My own work has been supported by the National Institute of Allergy and Infectious Diseases / National Institutes of Health.

\section{References}

Alexander, M. R.; Wheatley, A. K.; Center, R. J. \& Purcell, D. F. (2010). Efficient transcription through an intron requires the binding of an Sm-type U1 snRNP with intact stem loop II to the splice donor. Nucleic Acids Res, 38, 3041-53

Amelio, A. L.; Caputi, M. \& Conkright, M. D. (2009). Bipartite functions of the CREB coactivators selectively direct alternative splicing or transcriptional activation. Embo J, 28, 2733-47

Amendt, B. A.; Hesslein, D.; Chang, L. J. \& Stoltzfus, C. M. (1994). Presence of negative and positive cis-acting RNA splicing elements within and flanking the first tat coding exon of human immunodeficiency virus type 1. Mol. Cell. Biol., 14, 3960-3970

Ammosova, T.; Berro, R.; Jerebtsova, M.; Jackson, A.; Charles, S.; Klase, Z.; Southerland, W.; Gordeuk, V. R.; Kashanchi, F. \& Nekhai, S. (2006). Phosphorylation of HIV-1 Tat by CDK2 in HIV-1 transcription. Retrovirology, 3, 78

Ashe, M. P.; Griffin, P.; James, W. \& Proudfoot, N. J. (1995). Poly(A) site selection in the HIV1 provirus: inhibition of promoter-proximal polyadenylation by the downstream major splice donor site. Genes Dev, 9, 3008-25

Ashe, M. P.; Pearson, L. H. \& Proudfoot, N. J. (1997). The HIV-1 5' LTR poly(A) site is inactivated by U1 snRNP interaction with the downstream major splice donor site. Embo J, 16, 5752-63

Bakkour, N.; Lin, Y. L.; Maire, S.; Ayadi, L.; Mahuteau-Betzer, F.; Nguyen, C. H.; Mettling, C.; Portales, P.; Grierson, D.; Chabot, B.; Jeanteur, P.; Branlant, C.; Corbeau, P. \& Tazi, J. (2007). Small-molecule inhibition of HIV pre-mRNA splicing as a novel antiretroviral therapy to overcome drug resistance. PLoS Pathog, 3, 1530-9

Batsche, E.; Yaniv, M. \& Muchardt, C. (2006). The human SWI/SNF subunit Brm is a regulator of alternative splicing. Nat Struct Mol Biol, 13, 22-9

Benkirane, M.; Chun, R. F.; Xiao, H.; Ogryzko, V. V.; Howard, B. H.; Nakatani, Y. \& Jeang, K. T. (1998). Activation of integrated provirus requires histone acetyltransferase. p300 and P/CAF are coactivators for HIV-1 Tat. J Biol Chem, 273, 24898-905

Bennasser, Y.; Le, S. Y.; Benkirane, M. \& Jeang, K. T. (2005). Evidence that HIV-1 encodes an siRNA and a suppressor of RNA silencing. Immunity, 22, 607-19

Bennasser, Y.; Le, S. Y.; Yeung, M. L. \& Jeang, K. T. (2004). HIV-1 encoded candidate microRNAs and their cellular targets. Retrovirology, 1, 43

Bentley, D. (2002). The mRNA assembly line: transcription and processing machines in the same factory. Curr Opin Cell Biol, 14, 336-42 
Bentley, D. L. (2005). Rules of engagement: co-transcriptional recruitment of pre-mRNA processing factors. Curr Opin Cell Biol, 17, 251-6

Berkhout, B.; Silverman, R. H. \& Jeang, K. T. (1989). Tat trans-activates the human immunodeficiency virus through a nascent RNA target. Cell, 59, 273-82

Berro, R.; Kehn, K.; de la Fuente, C.; Pumfery, A.; Adair, R.; Wade, J.; Colberg-Poley, A. M.; Hiscott, J. \& Kashanchi, F. (2006). Acetylated Tat regulates human immunodeficiency virus type 1 splicing through its interaction with the splicing regulator p32. J Virol, 80, 3189-204

Bevec, D.; Jaksche, H.; Oft, M.; Wohl, T.; Himmelspach, M.; Pacher, A.; Schebesta, M.; Koettnitz, K.; Dobrovnik, M.; Csonga, R.; Lottspeich, F. \& Hauber, J. (1996). Inhibition of HIV-1 replication in lymphocytes by mutants of the Rev cofactor eIF5A. Science, 271, 1858-60

Black, D. L. (2003). Mechanisms of alternative pre-messenger RNA splicing. Annu Rev Biochem, 72, 291-336

Blencowe, B. J. (2000). Exonic splicing enhancers: mechanism of action, diversity and role in human genetic diseases. Trends Biochem Sci, 25, 106-10

Bogerd, H. P.; Fridell, R. A.; Madore, S. \& Cullen, B. R. (1995). Identification of a novel cellular cofactor for the Rev/Rex class of retroviral regulatory proteins. Cell, 82, 485-94

Boris-Lawrie, K.; Roberts, T. M. \& Hull, S. (2001). Retroviral RNA elements integrate components of post-transcriptional gene expression. Life Sci, 69, 2697-709

Boulanger, M. C.; Liang, C.; Russell, R. S.; Lin, R.; Bedford, M. T.; Wainberg, M. A. \& Richard, S. (2005). Methylation of Tat by PRMT6 regulates human immunodeficiency virus type 1 gene expression. J Virol, 79, 124-31

Brady, J. \& Kashanchi, F. (2005). Tat gets the "green" light on transcription initiation. Retrovirology, 2, 69

Bres, V.; Gomes, N.; Pickle, L. \& Jones, K. A. (2005). A human splicing factor, SKIP, associates with P-TEFb and enhances transcription elongation by HIV-1 Tat. Genes Dev, 19, 1211-26

Bres, V.; Kiernan, R.; Emiliani, S. \& Benkirane, M. (2002). Tat acetyl-acceptor lysines are important for human immunodeficiency virus type-1 replication. J Biol Chem, 277, 22215-21

Bres, V.; Kiernan, R. E.; Linares, L. K.; Chable-Bessia, C.; Plechakova, O.; Treand, C.; Emiliani, S.; Peloponese, J. M.; Jeang, K. T.; Coux, O.; Scheffner, M. \& Benkirane, M. (2003). A non-proteolytic role for ubiquitin in Tat-mediated transactivation of the HIV-1 promoter. Nat Cell Biol, 5, 754-61

Bres, V.; Yoh, S. M. \& Jones, K. A. (2008). The multi-tasking P-TEFb complex. Curr Opin Cell Biol, 20, 334-40

Buhler, M. \& Moazed, D. (2007). Transcription and RNAi in heterochromatic gene silencing. Nat Struct Mol Biol, 14, 1041-1048

Buratowski, S. (2003). The CTD code. Nat Struct Biol, 10, 679-80

Buratowski, S. (2005). Connections between mRNA $3^{\prime}$ end processing and transcription termination. Curr Opin Cell Biol, 17, 257-61

Caceres, J. F.; Stamm, S.; Helfman, D. M. \& Krainer, A. R. (1994). Regulation of alternative splicing in vivo by overexpression of antagonistic splicing factors. Science, 265, 1706-1709 
Caldwell, R. L.; Egan, B. S. \& Shepherd, V. L. (2000). HIV-1 Tat represses transcription from the mannose receptor promoter. J Immunol, 165, 7035-41

Calzado, M. A.; Sancho, R. \& Munoz, E. (2004). Human immunodeficiency virus type 1 Tat increases the expression of cleavage and polyadenylation specificity factor 73kilodalton subunit modulating cellular and viral expression. J Virol, 78, 6846-54

Carty, S. M.; Goldstrohm, A. C.; Sune, C.; Garcia-Blanco, M. A. \& Greenleaf, A. L. (2000). Protein-interaction modules that organize nuclear function: FF domains of CA150 bind the phosphoCTD of RNA polymerase II. Proc Natl Acad Sci U S A, 97, 9015-20

Chang, D. D. \& Sharp, P. A. (1989). Regulation by HIV rev depends upon recognition of splice sites. Cell, 59, 789-795

Cherrington, J. \& Ganem, D. (1992). Regulation of polyadenylation in human immunodeficiency virus (HIV): contributions of promoter proximity and upstream sequences. Embo J, 11, 1513-24

Chiu, Y. L.; Ho, C. K.; Saha, N.; Schwer, B.; Shuman, S. \& Rana, T. M. (2002). Tat stimulates cotranscriptional capping of HIV mRNA. Mol Cell, 10, 585-97

Chua, J. H.; Armugam, A. \& Jeyaseelan, K. (2009). MicroRNAs: biogenesis, function and applications. Curr Opin Mol Ther, 11, 189-99

Col, E.; Caron, C.; Seigneurin-Berny, D.; Gracia, J.; Favier, A. \& Khochbin, S. (2001). The histone acetyltransferase, hGCN5, interacts with and acetylates the HIV transactivator, Tat. J Biol Chem, 276, 28179-84

Coley, W.; Van Duyne, R.; Carpio, L.; Guendel, I.; Kehn-Hall, K.; Chevalier, S.; Narayanan, A.; Luu, T.; Lee, N.; Klase, Z. \& Kashanchi, F. (2011). Absence of DICER in monocytes and its regulation by HIV-1. J Biol Chem, 285, 31930-43

Cullen, B. R. (2000). Nuclear RNA export pathways. Mol. Cell. Biol., 20, 4181-4187

Cullen, B. R. (2003). Nuclear mRNA export: insights from virology. Trends Biochem Sci, 28, 419-24

Damgaard, C. K.; Kahns, S.; Lykke-Andersen, S.; Nielsen, A. L.; Jensen, T. H. \& Kjems, J. (2008). A 5 ' splice site enhances the recruitment of basal transcription initiation factors in vivo. Mol Cell, 29, 271-8

de la Mata, M.; Alonso, C. R.; Kadener, S.; Fededa, J. P.; Blaustein, M.; Pelisch, F.; Cramer, P.; Bentley, D. \& Kornblihtt, A. R. (2003). A slow RNA polymerase II affects alternative splicing in vivo. Mol Cell, 12, 525-32

Deng, L.; Wang, D.; de la Fuente, C.; Wang, L.; Li, H.; Lee, C. G.; Donnelly, R.; Wade, J. D.; Lambert, P. \& Kashanchi, F. (2001). Enhancement of the p300 HAT activity by HIV1 Tat on chromatin DNA. Virology, 289, 312-26

Dorr, A.; Kiermer, V.; Pedal, A.; Rackwitz, H. R.; Henklein, P.; Schubert, U.; Zhou, M. M.; Verdin, E. \& Ott, M. (2002). Transcriptional synergy between Tat and PCAF is dependent on the binding of acetylated Tat to the PCAF bromodomain. Embo J, 21, 2715-23

Dowling, D.; Nasr-Esfahani, S.; Tan, C. H.; O'Brien, K.; Howard, J. L.; Jans, D. A.; Purcell, D. F.; Stoltzfus, C. M. \& Sonza, S. (2008). HIV-1 infection induces changes in expression of cellular splicing factors that regulate alternative viral splicing and virus production in macrophages. Retrovirology, 5, 18

Ensoli, B.; Barillari, G.; Salahuddin, S. Z.; Gallo, R. C. \& Wong-Staal, F. (1990). Tat protein of HIV-1 stimulates growth of cells derived from Kaposi's sarcoma lesions of AIDS patients. Nature, $345,84-6$ 
Exline, C. M.; Feng, Z. \& Stoltzfus, C. M. (2008). Negative and positive mRNA splicing elements act competitively to regulate human immunodeficiency virus type 1 vif gene expression. J Virol, 82, 3921-31

Fang, J.; Kubota, S.; Yang, B.; Zhou, N.; Zhang, H.; Godbout, R. \& Pomerantz, R. J. (2004). A DEAD box protein facilitates HIV-1 replication as a cellular co-factor of Rev. Virology, 330, 471-80

Fogel, B. L. \& McNally, M. T. (2000). A cellular protein, hnRNP H, binds to the negative regulator of splicing element from Rous sarcoma virus. J Biol Chem, 275, 3237132378

Fong, N. \& Bentley, D. L. (2001). Capping, splicing, and 3' processing are independently stimulated by RNA polymerase II: different functions for different segments of the CTD. Genes Dev, 15, 1783-95

Fong, Y. W. \& Zhou, Q. (2001). Stimulatory effect of splicing factors on transcriptional elongation. Nature, 414, 929-33.

Fritz, C. C.; Zapp, M. L. \& Green, M. R. (1995). A human nucleoporin-like protein that specifically interacts with HIV Rev. Nature, 376, 530-3

Fujinaga, K.; Irwin, D.; Huang, Y.; Taube, R.; Kurosu, T. \& Peterlin, B. M. (2004). Dynamics of human immunodeficiency virus transcription: $\mathrm{P}-\mathrm{TEFb}$ phosphorylates RD and dissociates negative effectors from the transactivation response element. Mol Cell Biol, 24, 787-95

Fukuhara, T.; Hosoya, T.; Shimizu, S.; Sumi, K.; Oshiro, T.; Yoshinaka, Y.; Suzuki, M.; Yamamoto, N.; Herzenberg, L. A. \& Hagiwara, M. (2006). Utilization of host SR protein kinases and RNA-splicing machinery during viral replication. Proc Natl Acad Sci U S A, 103, 11329-33

Garber, M. E.; Wei, P.; KewalRamani, V. N.; Mayall, T. P.; Herrmann, C. H.; Rice, A. P.; Littman, D. R. \& Jones, K. A. (1998). The interaction between HIV-1 Tat and human cyclin T1 requires zinc and a critical cysteine residue that is not conserved in the murine CycT1 protein. Genes Dev, 12, 3512-27

Gaynor, R. B. (1995). Regulation of HIV-1 gene expression by the transactivator protein tat. Curr. Top. Microbiol. Immunol., 193, 51-77

Giacca, M. (2004). The HIV-1 Tat protein: a multifaceted target for novel therapeutic opportunities. Curr Drug Targets Immune Endocr Metabol Disord, 4, 277-85

Gibellini, D.; Re, M. C.; La Placa, M. \& Zauli, G. (2002). Differentially expressed genes in HIV-1 tat-expressing CD4(+) T-cell line. Virus Res, 90, 337-45

Gilmartin, G. M.; Fleming, E. S.; Oetjen, J. \& Graveley, B. R. (1995). CPSF recognition of an HIV-1 mRNA 3'-processing enhancer: multiple sequence contacts involved in poly(A) site definition. Genes Dev, 9, 72-83

Goldstrohm, A. C.; Albrecht, T. R.; Sune, C.; Bedford, M. T. \& Garcia-Blanco, M. A. (2001). The transcription elongation factor CA150 interacts with RNA polymerase II and the pre-mRNA splicing factor SF1. Mol Cell Biol, 21, 7617-28

Graveley, B. R. (2000). Sorting out the complexity of SR protein functions. RNA, 6, 1197-211

Han, K.; Yeo, G.; An, P.; Burge, C. B. \& Grabowski, P. J. (2005). A combinatorial code for splicing silencing: UAGG and GGGG motifs. PLoS Biol, 3, e158

Hengartner, C. J.; Myer, V. E.; Liao, S. M.; Wilson, C. J.; Koh, S. S. \& Young, R. A. (1998). Temporal regulation of RNA polymerase II by Srb10 and Kin28 cyclin-dependent kinases. Mol Cell, 2, 43-53 
Hirose, Y. \& Ohkuma, Y. (2007). Phosphorylation of the C-terminal domain of RNA polymerase II plays central roles in the integrated events of eucaryotic gene expression. J Biochem, 141, 601-8

Hirose, Y.; Tacke, R. \& Manley, J. L. (1999). Phosphorylated RNA polymerase II stimulates pre-mRNA splicing. Genes Dev, 13, 1234-9

Ho, C. K. \& Shuman, S. (1999). Distinct roles for CTD Ser-2 and Ser-5 phosphorylation in the recruitment and allosteric activation of mammalian mRNA capping enzyme. $\mathrm{Mol}$ Cell, 3, 405-11

Huang, L.; Bosch, I.; Hofmann, W.; Sodroski, J. \& Pardee, A. B. (1998). Tat protein induces human immunodeficiency virus type 1 (HIV-1) coreceptors and promotes infection with both macrophage-tropic and T-lymphotropic HIV-1 strains. J Virol, 72, 8952-60

Huang, Y. \& Steitz, J. A. (2005). SRprises along a messenger's journey. Mol Cell, 17, 613-5

Huigen, M. C.; Kamp, W. \& Nottet, H. S. (2004). Multiple effects of HIV-1 trans-activator protein on the pathogenesis of HIV-1 infection. Eur J Clin Invest, 34, 57-66

Invernizzi, C. F.; Xie, B.; Richard, S. \& Wainberg, M. A. (2006). PRMT6 diminishes HIV-1 Rev binding to and export of viral RNA. Retrovirology, 3, 93

Ivanov, D.; Kwak, Y. T.; Guo, J. \& Gaynor, R. B. (2000). Domains in the SPT5 protein that modulate its transcriptional regulatory properties. Mol Cell Biol, 20, 2970-83

Jablonski, J. A.; Amelio, A. L.; Giacca, M. \& Caputi, M. (2010). The transcriptional transactivator Tat selectively regulates viral splicing. Nucleic Acids Res, 38, 1249-60

Jablonski, J. A.; Buratti, E.; Stuani, C. \& Caputi, M. (2008). The secondary structure of the human immunodeficiency virus type 1 transcript modulates viral splicing and infectivity. J Virol, 82, 8038-50

Jablonski, J. A. \& Caputi, M. (2009). Role of cellular RNA processing factors in human immunodeficiency virus type $1 \mathrm{mRNA}$ metabolism, replication, and infectivity. $J$ Virol, 83, 981-92

Jacquenet, S.; Decimo, D.; Muriaux, D. \& Darlix, J. L. (2005). Dual effect of the SR proteins ASF/SF2, SC35 and 9G8 on HIV-1 RNA splicing and virion production. Retrovirology, 2, 33

Kameoka, S.; Duque, P. \& Konarska, M. M. (2004). p54(nrb) associates with the 5 ' splice site within large transcription/splicing complexes. Embo J, 23, 1782-91

Kamine, J.; Elangovan, B.; Subramanian, T.; Coleman, D. \& Chinnadurai, G. (1996). Identification of a cellular protein that specifically interacts with the essential cysteine region of the HIV-1 Tat transactivator. Virology, 216, 357-66

Kaul, D.; Ahlawat, A. \& Gupta, S. D. (2009). HIV-1 genome-encoded hiv1-mir-H1 impairs cellular responses to infection. Mol Cell Biochem, 323, 143-8

Kiernan, R. E.; Vanhulle, C.; Schiltz, L.; Adam, E.; Xiao, H.; Maudoux, F.; Calomme, C.; Burny, A.; Nakatani, Y.; Jeang, K. T.; Benkirane, M. \& Van Lint, C. (1999). HIV-1 tat transcriptional activity is regulated by acetylation. Embo J, 18, 6106-18

Kim, J. B. \& Sharp, P. A. (2001). Positive transcription elongation factor B phosphorylates hSPT5 and RNA polymerase II carboxyl-terminal domain independently of cyclindependent kinase-activating kinase. J Biol Chem, 276, 12317-23

King, J. E.; Eugenin, E. A.; Buckner, C. M. \& Berman, J. W. (2006). HIV tat and neurotoxicity. Microbes Infect, 8, 1347-57 
Klase, Z.; Kale, P.; Winograd, R.; Gupta, M. V.; Heydarian, M.; Berro, R.; McCaffrey, T. \& Kashanchi, F. (2007). HIV-1 TAR element is processed by Dicer to yield a viral micro-RNA involved in chromatin remodeling of the viral LTR. BMC Mol Biol, 8, 63

Klase, Z.; Winograd, R.; Davis, J.; Carpio, L.; Hildreth, R.; Heydarian, M.; Fu, S.; McCaffrey, T.; Meiri, E.; Ayash-Rashkovsky, M.; Gilad, S.; Bentwich, Z. \& Kashanchi, F. (2009). HIV-1 TAR miRNA protects against apoptosis by altering cellular gene expression. Retrovirology, 6, 18

Komarnitsky, P.; Cho, E. J. \& Buratowski, S. (2000). Different phosphorylated forms of RNA polymerase II and associated mRNA processing factors during transcription. Genes Dev, 14, 2452-60

Kornblihtt, A. R. (2005). Promoter usage and alternative splicing. Curr Opin Cell Biol, 17, 2628

Kornblihtt, A. R. (2007). Coupling transcription and alternative splicing. Adv Exp Med Biol, $623,175-89$

Krecic, A. M. \& Swanson, M. S. (1999). hnRNP complexes: composition, structure, and function. Curr. Opin. Cell. Biol., 11, 363-71

Kwek, K. Y.; Murphy, S.; Furger, A.; Thomas, B.; O'Gorman, W.; Kimura, H.; Proudfoot, N. J. \& Akoulitchev, A. (2002). U1 snRNA associates with TFIIH and regulates transcriptional initiation. Nat Struct Biol, 9, 800-5

Lamers, S. L.; Salemi, M.; Galligan, D. C.; de Oliveira, T.; Fogel, G. B.; Granier, S. C.; Zhao, L.; Brown, J. N.; Morris, A.; Masliah, E. \& McGrath, M. S. (2009). Extensive HIV-1 intra-host recombination is common in tissues with abnormal histopathology. PLoS One, 4, e5065

Li, A. G.; Piluso, L. G.; Cai, X.; Gadd, B. J.; Ladurner, A. G. \& Liu, X. (2007). An acetylation switch in p53 mediates holo-TFIID recruitment. Mol Cell, 28, 408-21

Lin, S.; Coutinho-Mansfield, G.; Wang, D.; Pandit, S. \& Fu, X. D. (2008). The splicing factor SC35 has an active role in transcriptional elongation. Nat Struct Mol Biol, 15, 819-26

Mahmoudi, T.; Parra, M.; Vries, R. G.; Kauder, S. E.; Verrijzer, C. P.; Ott, M. \& Verdin, E. (2006). The SWI/SNF chromatin-remodeling complex is a cofactor for Tat transactivation of the HIV promoter. J Biol Chem, 281, 19960-8

Maldarelli, F.; Martin, M. A. \& Strebel, K. (1991). Identification of postranscriptionally active inhibitory sequences in human immunodeficiency virus type I RNA: novel level of gene regulation. J. Virol., 65, 5732-5743

Marcello, A.; Zoppe, M. \& Giacca, M. (2001). Multiple modes of transcriptional regulation by the HIV-1 Tat transactivator. IUBMB Life, 51, 175-81

Marzio, G.; Tyagi, M.; Gutierrez, M. I. \& Giacca, M. (1998). HIV-1 tat transactivator recruits p300 and CREB-binding protein histone acetyltransferases to the viral promoter. Proc Natl Acad Sci U S A, 95, 13519-24

McLaren, M.; Asai, K. \& Cochrane, A. (2004). A novel function for Sam68: enhancement of HIV-1 RNA 3' end processing. Rna, 10, 1119-29

McLaren, M.; Marsh, K. \& Cochrane, A. (2008). Modulating HIV-1 RNA processing and utilization. Front Biosci, 13, 5693-707

Mikaelian, I.; Krieg, M.; Gait, M. J. \& Karn, J. (1996). Interaction of INS (CRS) elements and the splicing machinery regulate the production of Rev-responsive mRNAs. J Mol Biol, 257, 246-264 
Min, H.; Chan, R. C. \& Black, D. L. (1995). The generally expressed hnRNP F is involved in a neural-specific pre-mRNA splicing event. Genes Dev., 9, 2659-2671

Misteli, T. \& Spector, D. L. (1999). RNA polymerase II targets pre-mRNA splicing factors to transcription sites in vivo. Mol Cell, 3, 697-705

Moore, M. J.; Query, C. C. \& Sharp, P. A. 1993. Splicing of precursors to mRNA by the spliceosome. In The RNA World, ed. R. F. Gesteland and J. F. Atkins, pp. 303-357. New York: Cold Spring Harbor Press

Mouland, A. J.; Coady, M.; Yao, X. J. \& Cohen, E. A. (2002). Hypophosphorylation of poly(A) polymerase and increased polyadenylation activity are associated with human immunodeficiency virus type 1 Vpr expression. Virology, 292, 321-30

Nasioulas, G.; Zolotukhin, A. S.; Tabernero, C.; Solomin, L.; Cunningham, C. P.; Pavlakis, G. N. \& Felber, B. K. (1994). Elements distinct from human immunodeficiency virus type 1 splice sites are responsible for the Rev dependence of env mRNA. J Virol, 68, 2986-93

Neff, C. P.; Zhou, J.; Remling, L.; Kuruvilla, J.; Zhang, J.; Li, H.; Smith, D. D.; Swiderski, P.; Rossi, J. J. \& Akkina, R. (2011). An aptamer-siRNA chimera suppresses HIV-1 viral loads and protects from helper CD4(+) T cell decline in humanized mice. Sci Transl Med, 3, 66ra6

Ni, Z.; Schwartz, B. E.; Werner, J.; Suarez, J. R. \& Lis, J. T. (2004). Coordination of transcription, RNA processing, and surveillance by P-TEFb kinase on heat shock genes. Mol Cell, 13, 55-65

Olsen, H. S.; Cochrane, A. W. \& Rosen, C. (1992). Interaction of cellular factors with intragenic cis-acting repressive sequences within the HIV genome. Virology, 191, 709-15

Orphanides, G. \& Reinberg, D. (2002). A unified theory of gene expression. Cell, 108, 439-51

Ott, M.; Lovett, J. L.; Mueller, L. \& Verdin, E. (1998). Superinduction of IL-8 in T cells by HIV-1 Tat protein is mediated through NF-kappaB factors. J Immunol, 160, 2872-80

Ouellet, D. L.; Plante, I.; Landry, P.; Barat, C.; Janelle, M. E.; Flamand, L.; Tremblay, M. J. \& Provost, P. (2008). Identification of functional microRNAs released through asymmetrical processing of HIV-1 TAR element. Nucleic Acids Res, 36, 2353-65

Parada, C. A. \& Roeder, R. G. (1999). A novel RNA polymerase II-containing complex potentiates Tat-enhanced HIV-1 transcription. Embo J, 18, 3688-701

Pereira, L. A.; Bentley, K.; Peeters, A.; Churchill, M. J. \& Deacon, N. J. (2000). A compilation of cellular transcription factor interactions with the HIV-1 LTR promoter. Nucleic Acids Res, 28, 663-8

Peretti, S.; Schiavoni, I.; Pugliese, K. \& Federico, M. (2006). Selective elimination of HIV-1infected cells by Env-directed, HIV-1-based virus-like particles. Virology, 345, 11526

Perron, M. P. \& Provost, P. (2008). Protein interactions and complexes in human microRNA biogenesis and function. Front Biosci, 13, 2537-47

Peterlin, B. M. \& Price, D. H. (2006). Controlling the elongation phase of transcription with P-TEFb. Mol Cell, 23, 297-305

Pollard, V. W. \& Malim, M. H. (1998). The HIV-1 rev protein. Annu. Rev. Microbiol., 52, 491532

Proudfoot, N. J.; Furger, A. \& Dye, M. J. (2002). Integrating mRNA processing with transcription. Cell, 108, 501-12. 
Purcell, D. F. J. \& Martin, M. A. (1993). Alternative splicing of human immunodeficiency virus type 1 mRNA modulates viral protein expression, replication and infectivity. J. Virol., 67, 6365-6378

Purzycka, K. J. \& Adamiak, R. W. (2008). The HIV-2 TAR RNA domain as a potential source of viral-encoded miRNA. A reconnaissance study. Nucleic Acids Symp Ser (Oxf), 5112

Raha, T.; Cheng, S. W. \& Green, M. R. (2005). HIV-1 Tat stimulates transcription complex assembly through recruitment of TBP in the absence of TAFs. PLoS Biol, 3, e44

Reddy, T. R.; Tang, H.; Xu, W. \& Wong-Staal, F. (2000). Sam68, RNA helicase A and Tap cooperate in the post-transcriptional regulation of human immunodeficiency virus and type D retroviral mRNA. Oncogene, 19, 3570-5

Reddy, T. R.; Xu, W.; Mau, J. K.; Goodwin, C. D.; Suhasini, M.; Tang, H.; Frimpong, K.; Rose, D. W. \& Wong-Staal, F. (1999). Inhibition of HIV replication by dominant negative mutants of Sam68, a functional homolog of HIV-1 Rev. Nat Med, 5, 635-42

Rodriguez, M. S.; Dargemont, C. \& Stutz, F. (2004). Nuclear export of RNA. Biol Cell, 96, 63955

Rubartelli, A.; Poggi, A.; Sitia, R. \& Zocchi, M. R. (1998). HIV-I Tat: a polypeptide for all seasons. Immunol Today, 19, 543-5

Ruhl, M.; Himmelspach, M.; Bahr, G. M.; Hammerschmid, F.; Jaksche, H.; Wolff, B.; Aschauer, H.; Farrington, G. K.; Probst, H.; Bevec, D. \& et al. (1993). Eukaryotic initiation factor $5 \mathrm{~A}$ is a cellular target of the human immunodeficiency virus type 1 Rev activation domain mediating trans-activation. J Cell Biol, 123, 1309-20

Sanchez-Alvarez, M.; Goldstrohm, A. C.; Garcia-Blanco, M. A. \& Sune, C. (2006). Human transcription elongation factor CA150 localizes to splicing factor-rich nuclear speckles and assembles transcription and splicing components into complexes through its amino and carboxyl regions. Mol Cell Biol, 26, 4998-5014

Schaub, M. C.; Lopez, S. R. \& Caputi, M. (2007). Members of the heterogeneous nuclear ribonucleoprotein $\mathrm{H}$ family activate splicing of an HIV-1 splicing substrate by promoting formation of ATP-dependent spliceosomal complexes. J Biol Chem, 282, 13617-26

Secchiero, P.; Zella, D.; Capitani, S.; Gallo, R. C. \& Zauli, G. (1999). Extracellular HIV-1 tat protein up-regulates the expression of surface CXC-chemokine receptor 4 in resting CD4+ T cells. J Immunol, 162, 2427-31

Shatkin, A. J. \& Manley, J. L. (2000). The ends of the affair: capping and polyadenylation. Nat Struct Biol, 7, 838-42

Smith, M. J.; Kulkarni, S. \& Pawson, T. (2004). FF domains of CA150 bind transcription and splicing factors through multiple weak interactions. Mol Cell Biol, 24, 9274-85

Stoltzfus, C. M. \& Madsen, J. M. (2006). Role of viral splicing elements and cellular RNA binding proteins in regulation of HIV-1 alternative RNA splicing. Curr HIV Res, 4, 43-55

Suhasini, M. \& Reddy, T. R. (2009). Cellular proteins and HIV-1 Rev function. Curr HIV Res, 7, 91-100

Sune, C. \& Garcia-Blanco, M. A. (1999). Transcriptional cofactor CA150 regulates RNA polymerase II elongation in a TATA-box-dependent manner. Mol Cell Biol, 19, 471928 
Treand, C.; du Chene, I.; Bres, V.; Kiernan, R.; Benarous, R.; Benkirane, M. \& Emiliani, S. (2006). Requirement for SWI/SNF chromatin-remodeling complex in Tat-mediated activation of the HIV-1 promoter. Embo J, 25, 1690-9

Urcuqui-Inchima, S.; Castano, M. E.; Hernandez-Verdun, D.; St-Laurent, G., 3rd \& Kumar, A. (2006). Nuclear Factor 90, a cellular dsRNA binding protein inhibits the HIV Rev-export function. Retrovirology, 3, 83

Valente, S. T. \& Goff, S. P. (2006). Inhibition of HIV-1 gene expression by a fragment of hnRNP U. Mol Cell, 23, 597-605

Van Lint, C.; Quivy, V.; Demonte, D.; Chariot, A.; Vanhulle, C.; de Walque, S.; Gaudray, G.; Veithen, E.; Bours, V.; Piette, J. \& Burny, A. (2004). Molecular mechanisms involved in HIV-1 transcriptional latency and reactivation: implications for the development of therapeutic strategies. Bull Mem Acad R Med Belg, 159, 176-89

Verdel, A.; Jia, S.; Gerber, S.; Sugiyama, T.; Gygi, S.; Grewal, S. I. \& Moazed, D. (2004). RNAi-mediated targeting of heterochromatin by the RITS complex. Science, 303, 672-6

Verdin, E.; Paras, P., Jr. \& Van Lint, C. (1993). Chromatin disruption in the promoter of human immunodeficiency virus type 1 during transcriptional activation. Embo J, 12, 3249-59

Wada, T.; Orphanides, G.; Hasegawa, J.; Kim, D. K.; Shima, D.; Yamaguchi, Y.; Fukuda, A.; Hisatake, K.; Oh, S.; Reinberg, D. \& Handa, H. (2000). FACT relieves DSIF/NELFmediated inhibition of transcriptional elongation and reveals functional differences between P-TEFb and TFIIH. Mol Cell, 5, 1067-72

Wada, T.; Takagi, T.; Yamaguchi, Y.; Ferdous, A.; Imai, T.; Hirose, S.; Sugimoto, S.; Yano, K.; Hartzog, G. A.; Winston, F.; Buratowski, S. \& Handa, H. (1998a). DSIF, a novel transcription elongation factor that regulates RNA polymerase II processivity, is composed of human Spt4 and Spt5 homologs. Genes Dev, 12, 343-56

Wada, T.; Takagi, T.; Yamaguchi, Y.; Watanabe, D. \& Handa, H. (1998b). Evidence that P$\mathrm{TEFb}$ alleviates the negative effect of DSIF on RNA polymerase II-dependent transcription in vitro. Embo J, 17, 7395-403

Wei, P.; Garber, M. E.; Fang, S. M.; Fischer, W. H. \& Jones, K. A. (1998). A novel CDK9associated C-type cyclin interacts directly with HIV-1 Tat and mediates its highaffinity, loop-specific binding to TAR RNA. Cell, 92, 451-62

Weichs an der Glon, C.; Monks, J. \& Proudfoot, N. J. (1991). Occlusion of the HIV poly(A) site. Genes Dev, 5, 244-53

Weissman, J. D.; Brown, J. A.; Howcroft, T. K.; Hwang, J.; Chawla, A.; Roche, P. A.; Schiltz, L.; Nakatani, Y. \& Singer, D. S. (1998). HIV-1 tat binds TAFII250 and represses TAFII250-dependent transcription of major histocompatibility class I genes. Proc Natl Acad Sci U S A, 95, 11601-6

Wen, Y. \& Shatkin, A. J. (1999). Transcription elongation factor hSPT5 stimulates mRNA capping. Genes Dev, 13, 1774-9

Wentz, P. M.; Moore, B. E.; Cloyd, M. V.; Berget, S. M. \& Donehower, L. A. (1997). A naturally arising mutation of a potential silencer of exon splicing in human immunodeficiency virus type I induces dominant aberrant splicing and arrests virus production. J. Virol., 71, 8542-8551

Winter, J.; Jung, S.; Keller, S.; Gregory, R. I. \& Diederichs, S. (2009). Many roads to maturity: microRNA biogenesis pathways and their regulation. Nat Cell Biol, 11, 228-34 
Wodrich, H. \& Krausslich, H. G. (2001). Nucleocytoplasmic RNA transport in retroviral replication. Results Probl Cell Differ, 34, 197-217

Woychik, N. A. \& Hampsey, M. (2002). The RNA polymerase II machinery: structure illuminates function. Cell, 108, 453-63

Wu, R. F.; Ma, Z.; Myers, D. P. \& Terada, L. S. (2007). HIV-1 Tat activates dual Nox pathways leading to independent activation of ERK and JNK MAP kinases. J Biol Chem, 282, 37412-9

Yamaguchi, Y.; Takagi, T.; Wada, T.; Yano, K.; Furuya, A.; Sugimoto, S.; Hasegawa, J. \& Handa, H. (1999). NELF, a multisubunit complex containing RD, cooperates with DSIF to repress RNA polymerase II elongation. Cell, 97, 41-51

Yamamoto, T.; Omoto, S.; Mizuguchi, M.; Mizukami, H.; Okuyama, H.; Okada, N.; Saksena, N. K.; Brisibe, E. A.; Otake, K. \& Fuji, Y. R. (2002). Double-stranded nef RNA interferes with human immunodeficiency virus type 1 replication. Microbiol Immunol, 46, 809-17

Yang, X. J. \& Seto, E. (2008). Lysine acetylation: codified crosstalk with other posttranslational modifications. Mol Cell, 31, 449-61

Yedavalli, V. S.; Neuveut, C.; Chi, Y. H.; Kleiman, L. \& Jeang, K. T. (2004). Requirement of DDX3 DEAD box RNA helicase for HIV-1 Rev-RRE export function. Cell, 119, 38192

Zahler, A. M.; Damgaard, C. K.; Kjems, J. \& Caputi, M. (2004). SC35 and heterogeneous nuclear ribonucleoprotein A/B proteins bind to a juxtaposed exonic splicing enhancer/exonic splicing silencer element to regulate HIV-1 tat exon 2 splicing. $J$ Biol Chem, 279, 10077-84

Zhou, M.; Deng, L.; Kashanchi, F.; Brady, J. N.; Shatkin, A. J. \& Kumar, A. (2003). The Tat/TAR-dependent phosphorylation of RNA polymerase II C-terminal domain stimulates cotranscriptional capping of HIV-1 mRNA. Proc Natl Acad Sci U S A, 100, 12666-71

Zhou, M.; Halanski, M. A.; Radonovich, M. F.; Kashanchi, F.; Peng, J.; Price, D. H. \& Brady, J. N. (2000). Tat modifies the activity of CDK9 to phosphorylate serine 5 of the RNA polymerase II carboxyl-terminal domain during human immunodeficiency virus type 1 transcription. Mol Cell Biol, 20, 5077-86

Zhou, Q. \& Sharp, P. A. (1996). Tat-SF1: cofactor for stimulation of transcriptional elongation by HIV-1 Tat. Science, 274, 605-10 


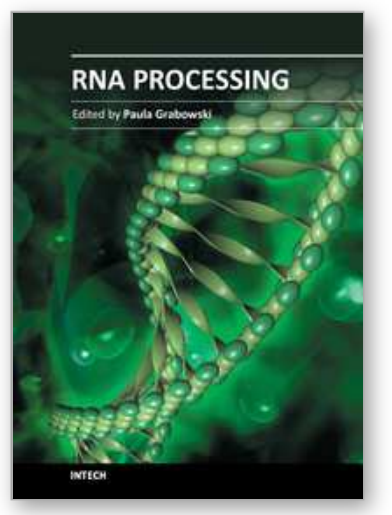

\section{RNA Processing}

Edited by Prof. Paula Grabowski

ISBN 978-953-307-557-0

Hard cover, 248 pages

Publisher InTech

Published online 29, August, 2011

Published in print edition August, 2011

RNA functions broadly as informational molecule, genome, enzyme and machinery for RNA processing. While these functions reflect ancient activities, they also remain vital components of contemporary biochemical pathways. In eukaryotic cells RNA processing impacts the biogenesis of RNA molecules of essentially every shape and function. The collection of articles in this volume describes the current state of understanding of the broad array of RNA processing events in animal and plant cells, key unanswered questions, and cutting edge approaches available to address these questions. Some questions discussed in this volume include, how viruses subvert the RNA processing machinery of the host cell, how the coordination of co-transcriptional RNA processing is regulated at the level of chromatin, the status of RNA processing in plant organelles, and how micro RNA machinery is biosynthesized and regulated.

\section{How to reference}

In order to correctly reference this scholarly work, feel free to copy and paste the following:

Massimo Caputi (2011). The Regulation of HIV-1 mRNA Biogenesis, RNA Processing, Prof. Paula Grabowski (Ed.), ISBN: 978-953-307-557-0, InTech, Available from: http://www.intechopen.com/books/rnaprocessing/the-regulation-of-hiv-1-mrna-biogenesis

\section{INTECH}

open science | open minds

\section{InTech Europe}

University Campus STeP Ri

Slavka Krautzeka 83/A

51000 Rijeka, Croatia

Phone: +385 (51) 770447

Fax: +385 (51) 686166

www.intechopen.com

\section{InTech China}

Unit 405, Office Block, Hotel Equatorial Shanghai

No.65, Yan An Road (West), Shanghai, 200040, China 中国上海市延安西路65号上海国际贵都大饭店办公楼 405 单元

Phone: +86-21-62489820

Fax: $+86-21-62489821$ 
(C) 2011 The Author(s). Licensee IntechOpen. This chapter is distributed under the terms of the Creative Commons Attribution-NonCommercialShareAlike-3.0 License, which permits use, distribution and reproduction for non-commercial purposes, provided the original is properly cited and derivative works building on this content are distributed under the same license. 